\title{
PENGARUH KONSENTRASI TELUR DAN CARBOXYMETHYL CELLULOSE TERHADAP KARAKTERISTIK FISIK, KIMIA DAN ORGANOLEPTIK MI KERING TEPUNG JALI (Coix lacrymal jobi-L) TERFERMENTASI
}

\section{The Effect of Egg and Carboxymethyl Cellulose Concentrations on Physical, Chemical, and Organoleptic Characteristics of Dry Noodles Fermented Jali Flour (Coix lacryma jobi-L)}

\author{
Aryani Zahara Kartini*, Widya Dwi Rukmi Putri \\ Jurusan Teknologi Hasil Pertanian, FTP Universitas Brawijaya Malang \\ JI. Veteran, Malang 65145 \\ *Penulis Korespondensi, Email: aryanizahara@gmail.com
}

\begin{abstract}
ABSTRAK
Mi umumnya terbuat dari tepung gandum. Namun, tepung gandum adalah komoditas impor, sehingga diperlukan diversifikasi dengan memanfaatkan bahan pangan lokal seperti tepung jali terfermentasi. Tujuan penelitian ini untuk mengetahui pengaruh konsentrasi telur dan Carboxymethyl Cellulose (CMC) terhadap karakteristik fisik, kimia, dan organoleptik mi kering berbasis tepung jali (Coix lacryma jobi-l) terfermentasi. Penelitian menggunakan Rancangan Acak Kelompok (RAK) dengan 2 faktor, faktor I yaitu konsentrasi telur (5\%, 10\%, dan $15 \%)$ dan faktor II konsentrasi CMC $(0 \%, 1 \%$, dan $4 \%)$. Perlakuan terbaik yaitu perlakuan penambahan telur 10\% b/b dan CMC 1\% b/b (T2C1) dengan kadar air (10,04\%), kadar pati $(56.25 \%)$, kadar protein $(7.62 \%)$, daya patah $(3.90 \mathrm{~N})$, daya putus $(0.50 \mathrm{~N})$, daya rehidrasi (222.44\%), waktu pemasakan (190 detik), derajat keputihan (74.32), warna (4.40) agak suka, aroma (4.48) agak suka, tekstur (4.92) agak suka, dan rasa (4.52) agak suka.
\end{abstract}

Kata Kunci: Carboxymethyl Cellulose (CMC), Jali (Coix Lachryma Jobi-L), Mi Kering, Telur, Tepung Jali Terfermentasi.

\begin{abstract}
Noodle is made of wheat flour. However, wheat flour is one of imported commodity. Futhermore, diversification efforts are required by utilizing local foodstuff such as fermented jali flour. The purpose is to know the effect of egg and Carboxymethyl Cellulose (CMC) concentrations on physical, chemical, and organoleptic characteristics of dry noodles fermented jali flour (Coix lacryma jobi-L). The research used Randomized Block Design method with 2 factors. The factors are egg concentration (5\%, 10\% and 15\%) and CMC concentration (0\%, $1 \%$ and $2 \%$ ). The best treatment is the addition of egg treatment $10 \% \mathrm{~W} / \mathrm{W}$ and CMC 1\% w/w (T2C1) which has the characteristic as follow: water (10.04\%), starch $(56.5 \%)$, protein $(7.62 \%)$, broken power $(3.90 \mathrm{~N})$, breaking power $(0.50 \mathrm{~N})$, power rehydration (222.44\%), cooking time (190 seconds), the degree of whiteness $(74.32)$, color $(4,40)$ rather like, aroma (4.48) rather like, texture (4.92) rather Like, and taste (4.52) rather like.
\end{abstract}

Keywords: Carboxymethyl Cellulose (CMC), Dry Noodles, Egg, Jali (Coix Lacryma Jobi-L), Fermented Jali Flour

\section{PENDAHULUAN}

Mi kering merupakan produk pangan yang sangat populer. Pangsa pasar mi secara nasional selalu meningkat dari tahun ke tahun sebesar 1-3\% (Canadean, 2014). Pada umumnya mi kering terbuat dari tepung terigu. Tepung gandum adalah komoditas impor, sehingga diperlukan diversifikasi dengan memanfaatkan bahan pangan lokal seperti tepung 
jali (Coix Lachryma Jobi-L) terfermentasi. Jali memiliki komposisi kimia yang hampir sama dengan gandum. Jali mengandung $11.2 \%$ air, $65.3 \%$ karbohidrat, $15.4 \%$ protein, $6.2 \%$ lemak, serat $0.8 \%$, abu $1.9 \%$ dan mineral. Tidak hanya dari segi kandungannya. Jali merupakan salah satu tanaman yang dapat tumbuh dengan kelembapan udara diatas $90 \%$ serta tahan dengan serangan hama dan perubahan iklim (Burnette,2012).

Namun disatu sisi, jali memiliki ukuran granula yang keras serta berbentuk bulat dan polygonal dengan ukuran rata-rata 11.68-12.29 $\mu \mathrm{m}$ (Chaisiricharoenkul et al, 2011). Dengan demikian, ukuran granula pati jali yang keras dan besar menghasilkan karakteristik tepung jali yang kurang baik, sehingga dalam pembuatan tepung jali dilakukan penepungan dengan metode basah yaitu fermentasi. Syahputri (2014) dalam penelitiannya mengemukakan tepung jali terfermentasi 72 jam menghasilkan penampakan fisik yang lebih baik.

Penggunaan tepung jali terfermentasi memiliki kekurangan yaitu mi kering menjadi mudah patah dan kurang elastis. Penambahan pengemulsi dan penstabil pada mi mampu memperbaiki karakteristik mi kering. Pada penelitian ini pengemulsi yang digunakan yaitu telur. Penstabil yang digunakan yaitu Carboxymethyl Cellulose (CMC).

\section{BAHAN DAN METODE}

\section{Bahan}

Bahan yang digunakan dalam pembuatan mi kering adalah tepung jali terefermentasi, telur ayam (Bima), CMC, air, air kansui, dan garam. Bahan yang digunakan untuk analisis fisik dan kimia adalah $\mathrm{H}_{2} \mathrm{SO}_{4} 37 \%$ pro-analisis, asam borat $3 \%$ pro-analisis, $\mathrm{NaOH} 30 \%$ teknis, tablet kjedal, indikator $\mathrm{PP}$, methyl red, $\mathrm{HCl} 0,1 \mathrm{~N}, \mathrm{HCl} 0,02 \mathrm{~N}$, petroleum eter pro-analisis, alkohol $10 \%$ teknis, $\mathrm{HCl} 25 \%$ pro-analisis, $\mathrm{NaOH} 45 \%$ teknis, nelson $\mathrm{A}$ dan $\mathrm{B}$, arseno molibdat, dan akuades.

\section{Alat}

Alat yang digunakan dalam pembuatan mi kering adalah alat pencetak mi (Nagako) timbangan digital (Camry), alat kukus, dan kabinet pengering otomatis. Alat yang digunakan untuk analisis fisik dan kimia adalah pengering kabinet otomatis, oven listrik (Wtb. Binder), kompor listrik (Maspion), alat destruksi, alat destilasi (Buchi K-350), refluks, vortex (Lw. Scientific), spektrofotometer (20 D-Plus), tensile streght (Imada), shaker (Haidolp), timbangan analitik (Denver Instrument), dan colour reader (Konica Minota).

\section{Metode}

Metode penelitian ini menggunakan rancangan percobaan Rancangan Acak Kelompok (RAK) yang disusun secara faktorial dengan 2 faktor. Faktor I adalah konsentrasi telur terhadap tepung jali terfermentasi yang terdiri dari 3 level yaitu 5\%, 10\%, dan $15 \%$. Faktor II adalah konsentrasi CMC terhadap tepung jali terdiri dari 3 level yaitu $1 \%, 1,5 \%$, dan $2 \%$. Pada penelitian ini terdapat 9 kombinasi perlakuan dengan 27 satuan percobaan.

\section{Prosedur Analisis}

Parameter yang diamati secara fisik dan kimia meliputi kadar air, kadar pati, kadar protein, daya patah, daya putus, daya rehidrasi, waktu pemasakan, dan derajat keputihan. Parameter yang diamati secara organoleptik meliputi warna, aroma, tekstur, dan rasa. Hasil analisis akan diuji secara statistik dengan menggunakan analisis ragam (ANOVA) RAK 2 faktorial. Penentuan perlakuan terbaik secara fisik dan kimia dengan metode Multiple Objective Decision Making (MODM) oleh Zeleny. Kemudian perlakuan terbaik tersebut akan dibandingkan dengan produk komersil dengan metode Independent Sample $t$ Test. Penentuan perlakuan terbaik secara organoleptik dengan metode De Garmo. 
Pengaruh Konsentrasi Telur dan Carboxymethyl Cellulose - Kartini, dkk Jurnal Pangan dan Agroindustri Vol.6 No.2: 52-62, April 2018

\section{HASIL DAN PEMBAHASAN}

\section{Karakteristik Bahan Baku}

Analisis bahan baku dilakukan untuk mengetahui profil bahan baku yang digunakan untuk mi kering berbasis tepung jali terfermentasi.

Tabel 1. Karakteristik Kimia Bahan Baku

\begin{tabular}{lcc}
\hline Parameter & \multicolumn{1}{c}{ Biji Jali } & Tepung Jali Terfermentasi \\
\hline Air (\%) & $10.05 \pm 0.17$ & $9.18 \pm 0.11$ \\
Pati (\%) & $51.13 \pm 1.10$ & $37.46 \pm 6.15$ \\
$\quad$ Amilosa (\%) & $22.46 \pm 0.85$ & $29.95 \pm 0.20$ \\
$\quad$ Amilopektin (\%) & $77.54 \pm 0.85$ & $70.05 \pm 0.20$ \\
Protein (\%) & $9.07 \pm 2.04$ & $5.58 \pm 2.67$ \\
Serat kasar (\%) & $15.34 \pm 0.10$ & $13.84 \pm 0.89$ \\
Rendemen (\%) & - & $53.60 \pm 1.13$ \\
\hline
\end{tabular}

Keterangan: Hasil analisis merupakan rerata dua kali ulangan

Kadar air tepung jali terfermentasi (9.18\%) lebih rendah dibandingkan dengan kadar air biji jali $(10.05 \%)$. Hal ini dikarenakan pada saat pengeringan terjadinya reaksi endoterm. Reaksi endoterm merupakan perpindahan kalor dengan cara sistem menyerap kalor dari lingkungan (Wagiman, 2015). Biji jali yang berada di dalam pengering kabinet otomatis menyerap panas yang dialirkan pengering kabinet otomatis. Udara mempunyai kandungan uap air yang relatif lebih kecil daripada bahan sehingga dapat menghisap uap air dari bahan yang dikeringkan (Surya, 2009). Dengan demikian kadar air pada tepung fermentasi menjadi lebih rendah.

Kadar pati tepung jali terfermentasi (37.46\%) lebih rendah dibandingkan dengan kadar pati biji jali (51.13\%). Menurut Ryan (2010), selama proses perendaman memungkinkan terjadinya hidrolisis polimer penyusun bahan menjadi komponen yang lebih larut ke dalam media perendam sehingga dapat menyebabkan perubahan komponen kimia tepung. Selain itu, penurunan ini juga dikarenakan adanya mikroorganisme pada ragi tape yaitu Aspergillus $s p$ yang menghasilkan enzim amilase sehingga terjadinya pemecahan pati untuk membentuk molekul-molekul monosakarida (gula-gula sederhana) (Fatimah dan Lina 2013).

Kadar amilosa pada tepung jali terfermentasi (29.95\%) lebih tinggi dibandingkan kadar amilosa biji jali (22.46\%). Hal ini dikarenakan putusnya rantai cabang amilopektin pada ikatan a-1,6 glikosida dan terjadi pembentukan amilosa akibat adanya aktivitas enzim pullulanase selama proses fermentasi oleh mikroorganisme Bacillus sp (Nair et al, 2006). Pelepasan cabang (debranching) amilopektin oleh enzim pullulanase menghasilkan polimer glukosa rantai lurus yang merupakan amilosa dengan derajat polimerisasi (DP) lebih kecil sehingga amilosa yang dihasilkan menjadi lebih tinggi (Chen, 2003).

Kadar protein tepung jali terfermentasi $(9.07 \%)$ lebih rendah dibandingkan dengan kadar protein biji jali (5.58\%). Menurut Sumbono (2016) suhu dan lama pemanasan dapat mengakibatkan denaturasi. Ketika terjadinya denaturasi, protein akan berubah strukturnya sehingga sebagian berubah menjadi struktur primer. Ketika protein membentuk struktur primer, maka akan dengan mudah ikut menguap bersama air.

Kadar serat kasar tepung jali terfermentasi (13.84\%) lebih rendah dibandingkan dengan kadar serat kasar biji jali (15.34\%). Hal ini dikarenakan selama proses fermentasi berlangsung, terdapat mikroorganisme yang menghasilkan enzim sellulotik yang dapat menghancurkan dinding sel jali sedemikian rupa. Mikroba tersebut menghasilkan enzim yang menghidrolisis selulosa menjadi monosakarida (Lynd et al, 2002).

Rendemen tepung jali terfermentasi (53.60\%). Pada saat jali berbentuk biji, air di dalamnya dikeluarkan sehingga biji mengalami dehidrasi. Akibat ketiadaan air, struktur biji menjadi kuat dan keras. Ketika proses perendaman, air masuk ke dalam biji melalui proses osmosis (Oktovina, 2007). Menurut Yuan et al (2008) Hal tersebut mengakibatkan terjadi 
peristiwa melunaknya struktur jali yang awalnya membentuk kristalin yang memiliki tekstur keras menjadi lebih amorf. Peristiwa ini mengakibatkan kulit terluar biji jali akan terpisah dari komponen biji. Kulit biji memiliki struktur lebih keras dan sulit terdegradasi karena memiliki serat yang lebih tinggi (Campbell, 2000), sehingga akan sulit dihancurkan saat proses penggilingan. Dengan demikian hanya komponen dalam biji yang dapat tergiling secara sempurna dan menghasilkan ukuran partikel lebih kecil yang dapat tersaring pada ayakan 80 mesh.

\section{Karakteristik Kimia Mi Kering Tepung Jali Terfermentasi}

\section{Kadar Air}

Kadar air mi kering berbasis tepung jali terfermentasi dengan penambahan konsentrasi telur dan CMC berkisar antara 9.50\% hingga 10.29\%. Pada gambar 1 diketahui bahwa kadar air mi kering cenderung meningkat dengan bertambahnya konsentrasi telur dan CMC.

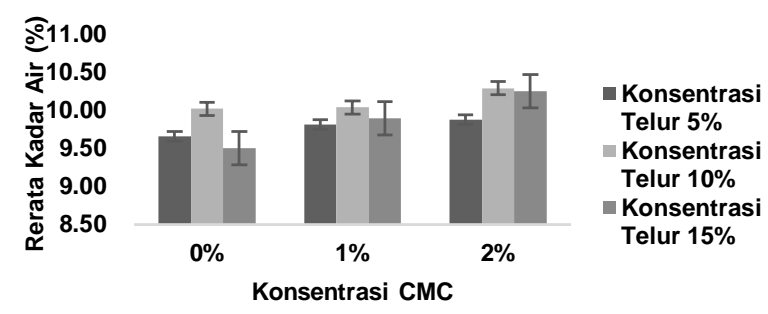

\section{Gambar 1 Grafik Kadar Air Mi Kering Berbasis Tepung Jali Terfermentasi Terhadap Penambahan Konsentrasi Telur dan CMC}

Hasil analisis ragam menunjukkan bahwa penambahan perbedaan konsentrasi telur dan CMC tidak memberikan pengaruh nyata $(\alpha=0.05)$ dan tidak ada interaksi. Menurut Dwiyanti dan Maulia (2007) Pada penelitiannya mengungkapkan bahwa kecepatan udara pengering pada alat pengering kabinet otomatis, yaitu $v=1 \mathrm{~m} / \mathrm{s}$ pada ukuran partikel $0.05 \mathrm{~cm}$, $0.04 \mathrm{~cm}$, dan $0.03 \mathrm{~cm}$. Sehingga ukuran mi yang seragam dengan tebal $1.00 \mathrm{~mm}$ dan lebar 1.00-1.50 mm menjadikan proses penguapan akan sama besar pada setiap perlakuannya. Selain itu, air yang terlepas adalah air bebas dan air yang terikat tidak ikut terlepas. Selama proses pengeringan air terikat pada mi tetap mempertahankan keberadaanya secara konsisten, sehingga ketika proses penguapan akan sama besar pada setiap perlakuannya.

\section{Kadar Pati}

Kadar pati mi kering berbasis tepung jali terfermentasi dengan penambahan konsentrasi telur dan CMC berkisar antara $36.88 \%$ hingga 59\%. Pada gambar 2 diketahui bahwa kadar pati mi kering tepung jali terfermentasi cenderung meningkat dengan bertambahnya konsentrasi telur dan CMC.

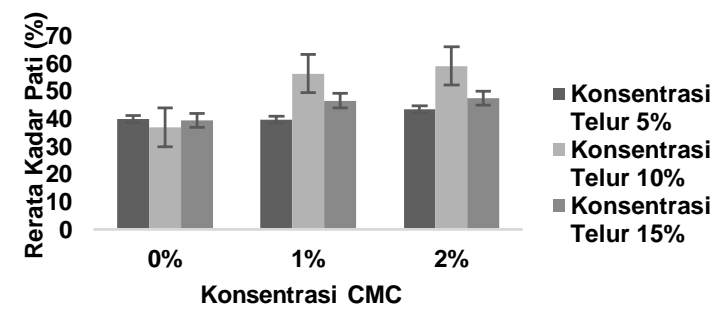

Gambar 2 Grafik Kadar Pati Mi Kering Berbasis Tepung Jali Terfermentasi Terhadap Penambahan Konsentrasi Telur dan CMC 
Hasil analisis ragam menunjukkan bahwa penambahan perbedaan konsentrasi telur dan CMC memberikan pengaruh nyata $(\alpha=0.05)$, tetapi tidak adanya interaksi. Hal ini terjadi karena selama proses perebusan pada pembuatan mi kering terjadi peristiwa leaching. Leaching yaitu suatu proses yang meliputi hidrasi dan pelarutan granula pati pada air. Leaching ini dapat menurunkan kadar pati pada tepung jali. Ketika pati dipanaskan, energi panas menyebabkan ikatan hidrogen pati menjadi melemah. Ikatan yang lemah memudahkan air masuk ke dalam granula dan terjadi pertukaran molekul pati menuju ke air yang dapat meningkatkan volume granula pati, sehingga sebagian molekul pati akan larut bersama air (Annison and Topping, 2000). Pada saat terjadinya peristiwa leaching, telur akan mempertahankan matriks pada mi. Sehingga molekul pati yang larut dalam air menjadi lebih sedikit.

Selain itu, penambahan CMC pada mi akan mempertahankan matriks yang terbentuk pada adonan (Glicksman, 2000). Dengan demikian pada proses perebusan jumlah padatan amilosa yang hilang tidak banyak. Dengan demikian penambahan telur mampu mempertahankan matriks kadar pati. Namun pada penambahan telur $15 \%$ terjadinya penurunan kadar pati. Hal ini dikarenakan telur memiliki kandungan air sebesar $85 \%$ (Coultate, 2009), sehingga memberikan penambahan jumlah air pada matriks pati yang membuat kekokohan matrik berkurang dan mi menjadi lembek.

\section{Kadar Protein}

Kadar protein mi kering tepung jali terfermentasi dengan penambahan konsentrasi telur dan CMC berkisar antara $7.06 \%$ hingga 10.26\%. Pada gambar 3 diketahui bahwa kadar protein mi kering berbasis tepung jali terfermentasi cenderung meningkat dengan bertambahnya konsentrasi telur dan CMC.

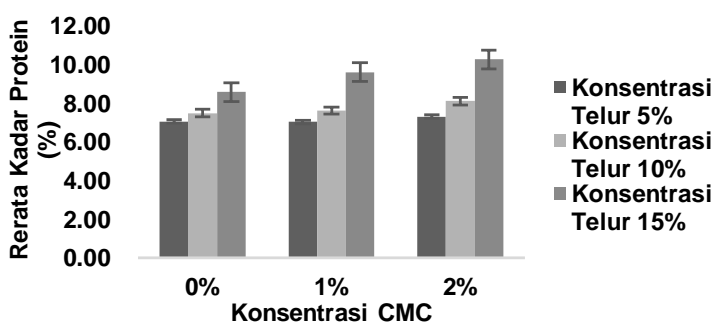

Gambar 3 Grafik Kadar Protein Mi Kering Berbasis Tepung Jali Terfermentasi Terhadap Penambahan Konsentrasi Telur dan CMC

Hasil analisis ragam menunjukkan bahwa penambahan perbedaan konsentrasi telur memberikan pengaruh nyata $(\alpha=0.05)$ namun penambahan perbedaan konsentrasi CMC tidak memberikan pengaruh nyata dan tidak ada interaksi. Hal ini dikarenakan kandungan protein pada telur yang tinggi. Menurut Evenepol et al (1998) Semakin tinggi penambahan telur maka akan berbanding lurus dengan jumlah protein pada produk pangan. Sedangkan kandungan pada CMC tidak mengandung protein.

\section{Karakteristik Fisik Mi Kering Tepung Jali Terfermentasi}

\section{Daya Patah}

Daya patah mi kering berbasis tepung jali terfermentasi dengan penambahan konsentrasi telur dan CMC berkisar antara $2.3 \mathrm{~N}$ hingga $3.9 \mathrm{~N}$. Pada gambar 4 diketahui bahwa daya patah mi kering cenderung fluktuatif dengan bertambahnya konsentrasi telur dan CMC. 


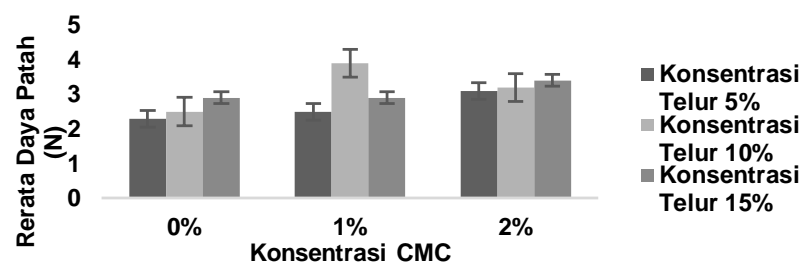

Gambar 4 Grafik Daya Patah Mi Kering Berbasis Tepung Jali Terfermentasi Terhadap Penambahan Konsentrasi Telur dan CMC

Hasil Analisis ragam menunjukkan bahwa penambahan perbedaan konsentrasi telur dan CMC memberikan pengaruh nyata $(\alpha=0.05)$ dan adanya interaksi antara kedua faktor. $\mathrm{Hal}$ ini dikarenakan adanya fungsi sinergis antara telur sebagai emulsifier dan CMC sebagai penstabil. Kuning telur merupakan salah satu emulsifier yang baik dikarenakan mengandung senyawa fosfolipid. Fosfolipid memiliki gugus hidrofilik yang dapat berikatan dengan air dan gugus hidrofobik yang dapat berikatan dengan lemak. Hal ini yang membuat terciptanya sistem emulsi (Lucero et al, 2008). Kekuatan daya patah juga dipengaruhi CMC yang berfungsi sebagai penstabil. CMC dalam larutan cenderung membentuk ikatan silang dalam molekul polimer yang menyebabkan molekul pelarut akan terjebak didalamnya sehingga terjadi imobilisasi molekul pelarut yang dapat membentuk struktur molekul yang kaku dan tahan terhadap tekanan (Kamal, 2010). Ikatan silang tersebut memperkuat ikatan hidrogen pada matriks pati sehingga menyebabkan molekul amilosa dan amilopektin cenderung membentuk ikatan hidrogen sendiri sehingga gel semakin kompak.

\section{Warna (Derajat Keputihan)}

Warna (derajat keputihan) mi kering berbasis tepung jali terfermentasi dengan penambahan konsentrasi telur dan CMC berkisar antara $66.33 \%$ hingga $74.32 \%$. Pada gambar 5 diketahui bahwa derajat keputihan mi kering cenderung menurun dengan bertambahnya konsentrasi telur dan CMC.

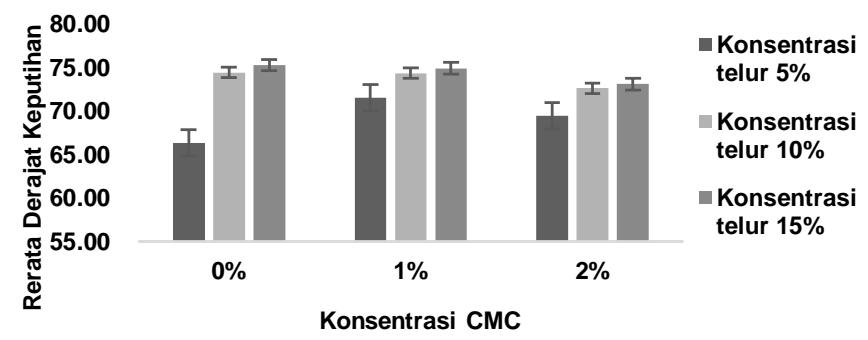

Gambar 5 Grafik Warna (Derajata Keputihan) Mi Kering Berbasis Tepung Jali Terfermentasi Terhadap Penambahan Konsentrasi Telur dan CMC

Hasil analisis ragam menunjukkan bahwa penambahan perbedaan konsentrasi telur dan CMC memberikan pengaruh nyata $(\alpha=0.05)$ dan adanya interaksi antara kedua faktor. Pada penambahan telur yang tinggi memberikan warna yang lebih terang. Menurut Biscaro \& Canniatti-Brazaca (2006) kuning telur memiliki pigmen xanthofil. Pigmen ini memberikan tingkat kecerahan pada mi. Namun disisi lain dengan adanya penambahan CMC akan mengakibatkan warna mi cenderung gelap. Hal ini dikarenakan tepung jali terfermentasi menghasilkan gula yang lebih banyak dari pada jenis tepung lainnya, sehingga lebih banyak gugus $\mathrm{OH}$ yang terbentuk. Disatu sisi, $\mathrm{CMC}$ juga memiliki gugus $\mathrm{OH}$ pada strukturnya (Wijayani dkk, 2005), sehingga jumlah gugus $\mathrm{OH}$ menjadi meningkat. Pada proses pengeringan pada mi kering, gugus $\mathrm{OH}$ tersebut berikatan dengan gugus amin pada protein telur yang membentuk reaksi mailard (Makfoeld, 2002). Hal ini membuat penambahan CMC akan memberikan pengaruh warna yang cenderung gelap. 


\section{Waktu Pemasakan}

Waktu pemasakan mi kering berbasis tepung jali terfermentasi dengan penambahan konsentrasi telur dan CMC berkisar antara 188.67 detik hingga 199.67 detik. Pada gambar 6 diketahui bahwa waktu pemasakan mi kering cenderung menurun dengan bertambahnya konsentrasi telur dan CMC.

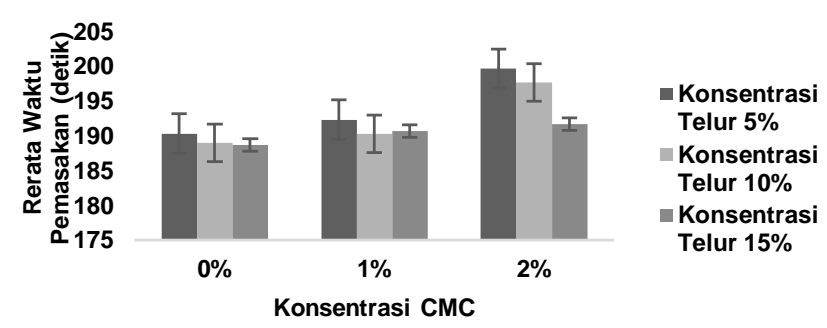

\section{Gambar 6 Grafik Waktu Pemasakan Mi Kering Berbasis Tepung Jali Terfermentasi Terhadap Penambahan Konsentrasi Telur dan CMC}

Hasil analisis ragam menunjukkan bahwa penambahan perbedaan konsentrasi telur tidak memberikan pengaruh nyata $(\alpha=0.05)$ namun penambahan perbedaan konsentrasi CMC memberikan pengaruh nyata dan tidak ada interaksi. Hal ini dikarenakan pada pemasakan mi kering menjadi mi matang terjadinya proses gelatinisasi yang kedua. Protein telur pada mi akan kembali menyerap air untuk membantu proses gelatinisasi kembali. Namun kemampuan protein telur tidak maksimal. Hal ini menjadikan waktu pemasakan pada mi tidak berbeda nyata.

Pada pemberian CMC yang lebih banyak akan mengakibatkan untaian mi menjadi keras. Hal ini dikarenakan CMC merupakan turunan selulosa dengan kelompok karboksimetil $(-\mathrm{CH} 2-\mathrm{COOH})$ terikat dengan beberapa kelompok hidroksil dari monomer glukopiranosa ( $\mathrm{Cp}$ Kelko, 2009). Ketika untaian mi menjadi keras. Kemampuan air berosmosis ke dalam mi menjadi lebih lama. Pada proses ini dibutuhkan energi yang lebih besar. Energi yang dibutuhkan akan berbanding lurus dengan waktu pemasakan. Dengan demikian untuk mematangkan mi dibutuhkan waktu yang lama.

\section{Daya Putus}

Daya putus mi kering berbasis tepung jali terfermentasi dengan penambahan konsentrasi telur dan CMC berkisar antara $0.2 \mathrm{~N}$ hingga $0.5 \mathrm{~N}$. Pada gambar 7 diketahui bahwa daya putus mi kering cenderung fluktuatif dengan bertambahnya konsentrasi telur dan CMC.

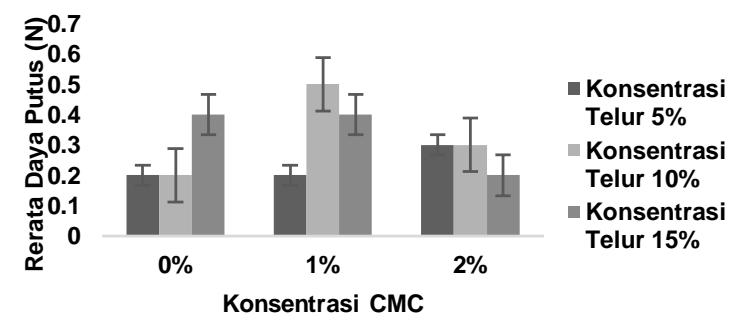

Gambar 7 Grafik Daya Putus Mi Kering Berbasis Tepung Jali Terfermentasi Terhadap Penambahan Konsentrasi Telur dan CMC

Hasil analisis ragam menunjukkan bahwa penambahan perbedaan konsentrasi telur tidak memberikan pengaruh nyata $(\alpha=0.05)$ namun penambahan perbedaan konsentrasi CMC memberikan pengaruh nyata dan tidak ada interkasi. Hal ini dikarenakan protein telah mengalami denaturasi akibat pemanasan yang berulang. Denaturasi dapat mengubah sifat 
protein yaitu berkurang aktivitasnya sebagai enzim, kelarutannya dalam garam-garam menurun, kemampuan membentuk gel berkurang, dan stabilitasnya menurun (Sumardjo, 2006), sedangkan Selama proses pemasakan mi matang terjadinya penyerapan air oleh CMC. Molekul-molekul air akan terperangkap dalam struktur gel yang dibentuk oleh CMC. Ketika CMC terdispersi dalam air, butiran CMC yang bersifat hidrofilik akan menyerap air dan membengkak. Air yang sebelumnya berada diluar sistem dan bebas bergerak menjadi tidak dapat bergerak lagi (Cahyadi, 2012). Ketika CMC menyerap air dari lingkungan menuju sistem, terjadi peristiwa proses gelatinisasi kembali pada mi. Namun pemberian CMC yang terlalu banyak akan membuat mi cenderung memperangkap air lebih banyak sehingga untaian mi menjadi lembek dan akan mudah putus.

\section{Daya Rehidrasi}

Daya rehidrasi mi kering berbasis tepung jali terfermentasi dengan penambahan konsentrasi telur dan CMC berkisar antara 219.15\% hingga $235.47 \%$. Pada gambar 8 diketahui bahwa daya rehidrasi mi kering cenderung meningkat dengan bertambahnya konsentrasi telur dan CMC.

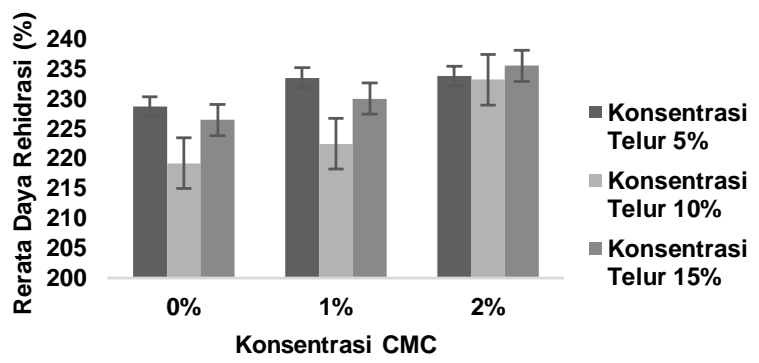

Gambar 8 Grafik Daya Rehidrasi Mi Kering Berbasis Tepung Jali Terfermentasi Terhadap Penambahan Konsentrasi Telur dan CMC

Hasil analisis ragam menunjukkan bahwa penambahan perbedaan konsentrasi telur dan $\mathrm{CMC}$ tidak memberikan pengaruh nyata $(\alpha=0.05)$ dan tidak adanya interaksi. Daya rehidrasi dipengaruhi beberapa hal antara lain kadar air, kandungan amilosa pada pati, dan komponen bahan. Saat perebusan berlangsung, pati pada mi telah mengalami retrogradsi akibat proses pengeringan, sehingga akan sulit bagi amilosa untuk melepaskan ikatannya dan cenderung memiliki kapasitas penyerapan air yang relatif rendah (Grenus et al, 1993). Jumlah kadar air pada mi setiap perlakuan yang sama besar mengakibatkan proses penyerapan air juga sama besar. Sealain itu, kemampuan fungsional telur berkurang karena telah mengalami denaturasi, sehingga CMC yang lebih banyak berkontribusi terhadap daya serap air mi. Penambahan konsentrasi CMC yang tidak terlalu jauh berbeda memungkin proses rehidrasi terjadi tapi tidak memberikan pengaruh yang nyata.

\section{Karakteristik Organoleptik Mi Kering Tepung Jali Terfermentasi}

Penilaian organoleptik pada mi kering tepung jali terfermentasi menggunakan metode uji hedonik atau kesukaan dari 25 panelis. Skala hedonik yang digunakan pada penelitian ini ialah skala 1-7 (sangat tidak suka hingga sangat suka) terdapat pada gambar 9 .

\section{Warna}

Uji kesukaan terhadap warna mi matang tepung jali terfermentasi berkisar antara 3.56 hingga 4.80. Hal ini menunjukkan bahwa rata-rata skor warna yang diberikan panelis berkisar antara netral (4) hingga agak suka (5).

\section{Aroma}

Uji kesukaan terhadap aroma mi matang tepung jali terfermentasi berkisar antara 4.20 hingga 4.76. Hal ini menunjukkan bahwa rata-rata skor aroma yang diberikan panelis berkisar antara netral (4) hingga agak suka (5). 


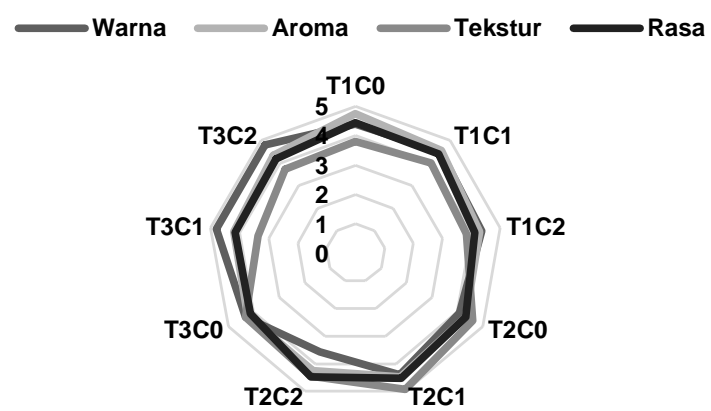

Gambar 9 Grafik Uji Organoleptik Mi Kering Tepung Jali Terfermentasi Metode Hedonik Akibat Perlakuan Penambahan Konsentrasi Telur dan CMC

\section{Rasa}

Uji kesukaan terhadap rasa mi matang tepung jali terfermentasi berkisar antara 4.12 hingga 4.82. Hal ini menunjukkan bahwa rata-rata skor rasa yang diberikan panelis berkisar antara netral (4) hingga agak suka (5).

\section{Tekstur}

Uji kesukaan terhadap tekstur mi matang tepung jali terfermentasi berkisar antara 3.36 hingga 4.92. Hal ini menunjukkan bahwa rata-rata skor tekstur yang diberikan panelis berkisar antara agak tidak suka (3) hingga agak suka (5).

\section{Perlakuan Terbaik Secara Fisik, Kimia, dan Organoleptik}

Perlakuan terbaik berdasarkan hasil analisis kimia, fisik, dan organoleptik pada tabel 2. Berdasarkan hasil penentuan perlakuan terbaik yaitu perlakuan T2C1 (konsentrasi telur $10 \%$ dan konsentrasi CMC 1\% dari bahan baku).

Tabel 2 Perlakuan Terbaik Secara Fisik, Kimia, dan Organoletik

\begin{tabular}{|c|c|}
\hline Parameter Fisik dan Kimia & Mi Kering Perlakuan Terbaik \\
\hline Kadar Air (\%) & $10.04 \pm 0.87$ \\
\hline Kadar Pati (\%) & $56.25 \pm 5.25$ \\
\hline Kadar Protein (\%) & $7.62 \pm 0.11$ \\
\hline Daya Patah (N) & $3.90 \pm 0.70$ \\
\hline Daya Putus (N) & $0.50 \pm 0.10$ \\
\hline Daya Rehidrasi (\%) & $222.44 \pm 3.81$ \\
\hline Waktu Pemasakan (s) & $190.00 \pm 5.51$ \\
\hline Derajat Keputihan & $74.32 \pm 0.40$ \\
\hline Parameter Organoleptik & Mi Kering Perlakuan Terbaik \\
\hline $\begin{array}{l}\text { Warna } \\
\text { Aroma } \\
\text { Tekstur } \\
\text { Rasa }\end{array}$ & $\begin{array}{l}\text { netral-agak suka } \\
\text { netral-agak suka } \\
\text { netral-agak suka } \\
\text { netral-agak suka }\end{array}$ \\
\hline
\end{tabular}

\section{Perbandingan Perlakuan Terbaik dengan Kontrol (Mi Komersil)}

Perbandingan perlakuan terbaik dengan kontrol (produk komersil) menggunakan metode uji $\mathrm{T}$ terdapat pada tabel 3 . Produk komersil yang digunakan merupakan produk mi telur 'Cap 3 Ayam' diproduksi oleh PT Indofood CBP Sukses Makmur. 
Tabel 3 Perbandingan Karakteristik Kimia dan Fisik Kontrol dengan Mi Kering Tepung jali terfermentasi Perlakuan Terbaik

\begin{tabular}{lrrc}
\hline \multirow{2}{*}{ Parameter } & \multicolumn{2}{c}{ Mi Kering } & \multirow{2}{*}{ Notasi } \\
\cline { 2 - 3 } & \multicolumn{1}{c}{ Kontrol } & \multicolumn{1}{c}{ T2C1 } & \\
\hline Kadar Air (\%) & $10.56 \pm 0.31$ & $10.04 \pm 0.87$ & tn \\
Kadar Pati (\%) & $45.47 \pm 4.07$ & $56.25 \pm 5.25$ & $* *$ \\
Kadar Protein (\%) & $10.09 \pm 0.38$ & $7.62 \pm 0.11$ & ** \\
Daya Patah (N) & $4.30 \pm 0.58$ & $3.90 \pm 0.70$ & tn \\
Daya Putus (N) & $0.43 \pm 0.05$ & $0.50 \pm 0.10$ & tn \\
Daya Rehidrasi (\%) & $209.33 \pm 8.91$ & $222.44 \pm 3.81$ & tn \\
Waktu Pemasakan (s) & $83.00 \pm 2.12$ & $190.00 \pm 2.89$ & $* *$ \\
Derajat Keputihan & $84.32 \pm 0.02$ & $74.32 \pm 0.40$ & $* *$ \\
\hline Keterangan: tn) tidak nyata; **) berbeda nyata & &
\end{tabular}

Keterangan: tn) tidak nyata; ${ }^{* *}$ ) berbeda nyata

Hasil perbandingan presentase kadar pati antara produk perlakuan terbaik dengan produk kontrol menghasilkan perbedaan yang nyata $(\alpha=0.05)$ antar keduanya. Kadar pati pada produk perlakuan lebih tinggi daripada produk kontrol. Hal tersebut dikarenakan jenis tepung yang digunakan berbeda, tepung yang digunakan pada produk perlakuan telah mengalami proses fermentasi sehingga presentase kadar pati cenderung lebih besar.

Perbandingan presentase kadar protein antara produk perlakuan terbaik dengan produk kontrol menghasilkan perbedaan yang nyata $(\alpha=0.05)$ antar keduanya. Kadar protein pada produk perlakuan lebih rendah daripada produk kontrol. Hal ini dikarenakan jumlah telur yang digunakan tidak sama berat. Selain itu pada produk kontrol terdapat penambahan TBHQ (tert-Buthylhydroquionone) yang merupakan jenis antioksidan buatan yang mampu menghambat proses oksidasi yang terjadi sehingga dapat mempertahankan jumlah protein dalam mi.

Perbandingan presentase waktu pemasakan antara produk perlakuan terbaik dengan produk kontrol menghasilkan perbedaan yang nyata $(\alpha=0.05)$ antar keduanya. Waktu pemasakan pada produk perlakuan relatif lebih lama daripada produk kontrol. Hal ini dikarenakan jenis tepung yang digunakan. Tepung terigu memiliki daya serap air sebesar $82 \%$ sehingga pada saat proses pemasakan mi kontrol relatif lebih cepat.

Perbandingan presentase derajat keputihan antara produk perlakuan terbaik dengan produk kontrol menghasilkan perbedaan yang nyata $(\alpha=0.05)$ antar keduanya. Derajat keputihan pada produk perlakuan lebih rendah daripada produk kontrol. Hal ini dikarenakan pada produk perlakuan tidak ditambahkan pewarna. Sedangkan pada produk kontrol ditambahkan pewarna buatan yaitu tartrazine sehingga warna mi nampak lebih cerah dan dapat stabil selama proses pemasakan.

\section{SIMPULAN}

Berdasarkan penelitian yang telah dilakukan dapat disimpulkan bahwa penambahan telur dan CMC berpengaruh nyata $(\alpha=0.05)$ terhadap kadar pati, kadar protein, daya patah, daya putus, waktu pemasakan, dan warna (derajat keputihan). Secara organoleptik, kedua perlakuan berpengaruh nyata $(\alpha=0.05)$ terhadap warna dan tekstur.

\section{DAFTAR PUSTAKA}

Annison, G and Topping D. L. 2000. Nutritional Role of Resistant Starch: Chemical Structure vs Physiology Fuction. Nutrition 14,1: 297-320.

Biscaro, L.M and Caniatti-Brazaca, S.G. 2006. Betacaroteno E Colesterol Em Gema De Ovos Obtidos De Poedeiras Que Receberam Diferentes Dietas. Ciência E Agrotecnologia. 30,6: 1130-1134. 
Burnette, Rick. 2012. Three Cheers for Job's Tears: Asia's Other Indigenous Grain. ECHO

Asia Notes: A Regional Upplement to ECHO Development Notes. London.

Cahyadi, Wisnu. 2012. Bahan Tambahan Pangan Edisi Kedua. Bumi Aksara. Jakarta.

Campbell, Neil A. 2002. Biologi Edisi Kelima Jilid 1. Erlangga. Jakarta.

Canadean. 2014. The Future of The Pasta and Noodles Market in Indonesia to 2018. http://www.marketresearch.com/product/sample-8316089.pdf. Tanggal akses: 22/9/2016.

Chaisiricharoenkul, J., S. Tongta and K-O Intarapichet. 2011. Stucture and Chemical and Physicochemical Properties og Job's Tear (Coix lachrymal jobi L.) Kernels and Flours. Science Techno 18,2: 109-122.

Chen, Z. 2003. Phsycochemical Properties of Sweet Potato Starches and Their Application in Noodle Products. Disertasi Doktor. Wageningen University. Belanda.

Coultate, T. P. 2009. Food: The Chemistry of Its Components. Royal Society of Chemistry. London.

Cp Kelko. 2009. Cellulose CMC. A Huber Company. USA.

Dwiyanti, Kristina dan Maulia, Nia. 2007. Pengaruh Ukuran Partikel Terhadap Laju Pengeringan Pupuk Za Dalam Tray Dryer. Skripsi. ITS. Surabaya.

Evenepoel, et al. 1998. Digestibility of Cook and Raw Egg Protein in Humans as Assessed by Stable Isotope Techniques. Disertasi Doktor. University Hospital Leuven. Belgium.

Fatimah, Ferbrina L.G., dan R.G. Lina. 2013. Kinetika Reaksi Fermentasi Alkohol dari Buah Salak. DepartemenTeknik Kimia. Universitas Sumatera Utara. Medan.

Glicksman, M. 2000. Food Hydrocoloids Volume 1. CRC Press, Inc. Florida.

Grenus, K.M., F. Hscih, and H.E. Huff. 1993. Extrusion an Extrudate Properties fo Rice Flour. Food Enginering. 18,1: 229-245.

Kamal, N. 2010. Pengaruh Bahan Aditif CMC (Carboxymethyl Cellulose) Terhadap Beberapa Parameter Pada Larutan Sukrosa. Teknologi. I,17: 78-84.

Lucero A, Nin MRN, Gunning AP, Morris VJ, Wilde PJ, And Patino JMR. 2008. Effect of Hydrocarbon Chain and $\mathrm{Ph}$ On Structural and Topographical Characteristics of Phospholipid Monolayers. Physical-Chemistry. 112,25: 7651-7661.

Lynd L.R., P.J. Weimer, W.H., WH van Zyl and I.S. Pretorius. 2002. Microbial Cellulose Utilizatin: Fundamentals and Biotechnology Microbiol. Molekul Biology. 6,3: 506-577.

Makfoeld, Djarir. 2002. Kamus Istilah Pangan dan Nutrisi. Kanisius. Yogyakarta.

Nair, S.U., Singhal, R.S., and M.Y. Kamat. 2006. Enhanced Production of Thermostable Pullulanase Type 1 Using Bacillus cereus FDTA 13 and Its Mutant. Food Techno. 44,1: 275-282.

Oktovina, Dian Malini. 2006. Contekan Rumus Biologi. Mizan. Jakarta.

Ryan, A. 2010. Kajian Sifat Fisikokimia Tepung Jagung di Tinjau dari Beberapa Varietas. Skripsi. Universitas Jenderal Sudirman. Purwokerto.

Sumardjo, Damin. 2006. Pengantar Kimia. EGC. Jakarta.

Sumbono, Aung. 2016. Biokimia Pangan Dasar. Deepublish. Jakarta.

Syahputri, Dwi Arinda. 2014. Pengaruh Fermentasi Jali Terhadap Karakteristik Cookies dan Roti Tawar. Jurnal Pangan dan Agroindustri 3,3: 984-995.

Wagiman, Lafifudin Basyir. 2015. Buku Cerdas Mata Pelajaran. Lembar Langit Indonesia. Jakarta.

Wijayani A. Khoirul U dan Siti T. 2005. Karakterisasi Carboxymethyl Cellulose (CMC) dari Eceng Gondok (Eichornia crassipes). Chemistry. 5,3: 228-231.

Yuan, M.L., Lu, Z.H., Cheng, Y.Q. dan Li, L.T. 2008. Effect of Spontaneous Fermentation on The Physical Properties of Corn Starch and Rheological Characteristics of Corn Starch Noodle. Food Engineering 85,1: 12-17. 